\title{
PENGEMBANGAN SERAT DAN EFISIENSI ENERGI PADA KOMBINASI REFINING KONSISTENSI TINGGI DAN RENDAH
}

\author{
Darono Wikanaji ${ }^{\text {a }}$, Trismawati ${ }^{\mathrm{b}}$ \\ a PT Kertas Leces (Persero), Probolinggo, e-mail : aji_darono@yahoo.co.id \\ ${ }^{\mathrm{b}}$ Fakultas Teknik Industri UPM Probolinggo
}

Diterima : 15 Maret 2011, Revisi akhir : 18 Mei 2011

\section{FIBER DEVELOPMENT AND ENERGY EFFICIENCY AT COMBINATION OF HIGH AND LOW CONSISTENCY OF REFINING}

\begin{abstract}
Refiner in the stock preparation unit of paper machine is the most determining factor of paper machine runnability and product quality. On the other hand, the refiner is the highest energy consuming machine. The operator only refers to freeness and strength properties achieved. The energy consumed and refiner capacity are lack of attention, so that refiner will mostly be the bottle neck and papermachine speed has to be decreased when one of the refiner faced any operational problem. The mass and energy tranfered is not known well but the effect of refining on papermachine runnability and product quality is significant. Combination of dual refining energy consumption for the process of refining at high consistency refiner and low consistency refiner in the process of sack kraft making is examined. Specific Refining Energy (SRE) used at a high consistency refiner (HC refiner consistency 32\%) is $100 \mathrm{kWh} / \mathrm{t}, 150 \mathrm{kWh} / \mathrm{t}, 200 \mathrm{kWh} / \mathrm{t}$, and $250 \mathrm{kWh} / \mathrm{t}$ while SRE used at low consistency refiner (LC refiner consistency of 5\%) is $20 \mathrm{kWh} / \mathrm{t}, 35 \mathrm{kWh} / \mathrm{t}, 50 \mathrm{kWh} / \mathrm{t}$ and $75 \mathrm{kWh} / \mathrm{t}$. In this research the fiber development, the energy efficiency, and the efficiency of the number of refiner used are also examined. The best result achived is in 2 HC Refiner SRE $200 \mathrm{kWh} / \mathrm{t}-2 \mathrm{LC}$ Refiner SRE $35 \mathrm{kWh} / \mathrm{t}-2 \mathrm{LC}$ refiner in standby position combination with total energy consumed 404,4 $\mathrm{kWh} / \mathrm{t}$, mean $0,5 \%$ energy saving based on operational standard 2 HC Refiner SRE $150 \mathrm{kWh} / \mathrm{t}$ and 4 LC Refiner SRE $50 \mathrm{kWh} / \mathrm{t}$ combination that consumed 406,5 $\mathrm{kWh} / \mathrm{t}$.
\end{abstract}

Key words : energy, refiner, segment, fiber development, product quality, runnability

\begin{abstract}
ABSTRAK
Refiner di unit persiapan bahan merupakan mesin penting dan sangat menentukan kelancaran mesin kertas dan kualitas kertas yang dihasilkan Di sisi lain mesin refiner merupakan mesin yang mengkonsumsi energi paling besar. Operator refiner sering hanya mengacu ke freeness dan kekuatan serat yang dapat dicapai tetapi kurang memperhatikan jumlah energi per ton pulp yang digunakan serta kapasitas optimal mesin refiner, sehingga refiner sering menjadi bottle neck dan mesin kertas terpaksa menurunkan kecepatan karena ada gangguan di salah satu mesin refiner. Perpindahan massa dan perpindahan energi refiner tidak diketahui secara pasti, akan tetapi terjadi dampak yang signifikan terhadap kelancaran mesin dan kualitas produk. Penelitian ini mengamati kombinasi pemakaian energi dual refining (proses refining pada refiner konsistensi tinggi dan refiner konsistensi rendah) dalam proses pembuatan sack kraft. Specific Refining Energy (SRE) yang digunakan pada refiner konsistensi tinggi (HC Refiner konsistensi 32\%) adalah 100 $\mathrm{kWh} / \mathrm{t}, 150 \mathrm{kWh} / \mathrm{t}, 200 \mathrm{kWh} / \mathrm{t}$, dan $250 \mathrm{kWh} / \mathrm{t}$ sementara SRE yang digunakan pada refiner konsistensi rendah (LC Refiner konsistensi 5\%) adalah $20 \mathrm{kWh} / \mathrm{t}, 35 \mathrm{kWh} / \mathrm{t}, 50 \mathrm{kWh} / \mathrm{t}$ dan $75 \mathrm{kWh} / \mathrm{t}$. Perkembangan serat, effisiensi energi dan efisiensi jumlah pemakaian refiner diamati. Hasil terbaik adalah pada kombinasi pemakaian 2 buah HC Refiner SRE $200 \mathrm{kWh} / \mathrm{t}$ - 2 buah LC Refiner SRE $35 \mathrm{kWh} / \mathrm{t}-2$ buah LC Refiner dalam keadaan standby, dengan total pemakaian energi $404,4 \mathrm{kWh} / \mathrm{t}$ yang dapat memberikan penghematan energi $0,5 \%$ per ton pulp dibandingkan dengan standar operasional kombinasi pemakaian 2 buah HC Refiner SRE $150 \mathrm{kWh} / \mathrm{t}$ - 4 buah LC Refiner SRE $35 \mathrm{kWh} / \mathrm{t}$ dengan total pemakaian energi 406,5 kWh/t.
\end{abstract}

Kata kunci : energi, refiner, segmen, perkembangan serat, kualitas dan kelancaran produksi 


\section{PENDAHULUAN}

Pengoperasian refiner sering hanya mengacu ke freeness dan kekuatan serat yang dapat dicapai tetapi berapa energi per ton pulp yang digunakan serta kapasitas optimal mesin refiner yang dapat dipakai kurang diperhatikan sehingga refiner sering menjadi bottle neck dan mesin kertas terpaksa turun speed pada saat ada gangguan di salah satu mesin refiner yang digunakan. Refiner dirancang untuk dapat mengantisipasi laju alir volumetris $\left(\mathrm{m}^{3} / \mathrm{jam}\right)$ maupun antisipasi throughput $(\mathrm{kg} / \mathrm{jam})$ dalam kisaran antara $75 \%$ sampai $150 \%$ kapasitas operasional, akan tetapi dalam operasional sehari-hari operator hanya sekedar berpola pikir bahwa laju alir pulp yang dipompa yang terpenting sudah masuk dalam kisaran kapasitas desain refiner dan freeness serta kekuatan serat yang dihasilkan sudah cukup mendukung kualitas serta kelancaran mesin.

Sementara itu untuk lebih mendukung kualitas produk dan kelancaran mesin kertas ditambahkan aditif ke bubur serat. Aditif yang diberikan di stock prep sebatas digunakan sebagai bahan kimia untuk memperbaiki penampilan visual atau sifat optis kertas dengan penambahan bahan warna dan Optical Brightening Agent (OBA), memperbaiki ratio serat per kertas memakai bahan retensi dan filler maupun sizing, menaikkan daya tahan kertas terhadap penetrasi air dengan penambahan AKD atau ASA dan sizing, menaikkan daya rekat antar serat dengan pati kationik, dll.
Dari sisi daya ikat antar serat, penambahan aditif seperti pati kationik berdampak kurang signifikan sepanjang pengembangan serat yang dihasilkan dari proses refining yang tidak optimal. Target daya ikat serat yang baik hanya dapat dicapai apabila pengembangan serat yang diinginkan dapat dicapai. Sebagaimana telah diketahui bahwa proses refining bertujuan untuk mendapatkan pengembangan serat yang optimal dalam arti serat dapat berkembang maksimal dengan pemakaian energi minimal. Variabel berpengaruh digambarkan pada Gambar 1, dan dampak yang dihasilkan adalah perubahan struktur dinding serat. Perubahan struktur dinding serat ini dapat berkontribusi positif dan negatif terhadap daya ikat antar serat. Perubahan struktur dinding serat yang diinginkan adalah perubahan struktur dinding serat yang berkontribusi positif terhadap daya ikat serat yang diperoleh dari tercapainya tingkat fleksibilitas serat melalui fibrilasi internal dan eksternal.

Intensitas refining $(\mathrm{W} / \mathrm{s})$ dan net spesific refining energy (SRE, $\mathrm{kWh} / \mathrm{t}$ ) harus dikontrol untuk mendapatkan perubahan struktur dinding serat yang diinginkan yaitu pengembangan serat yang optimal (Gambar 1). Variable proses pasif harus sudah ditentukan diawal proses sebelum proses refining dilakukan, bahkan sebelum jenis produk kertas yang akan dibuat ditentukan, dengan demikian sangat terkait dengan perencanaan produksi dan order pasar. Variable proses aktif dapat diatur saat proses refining sedang berjalan.

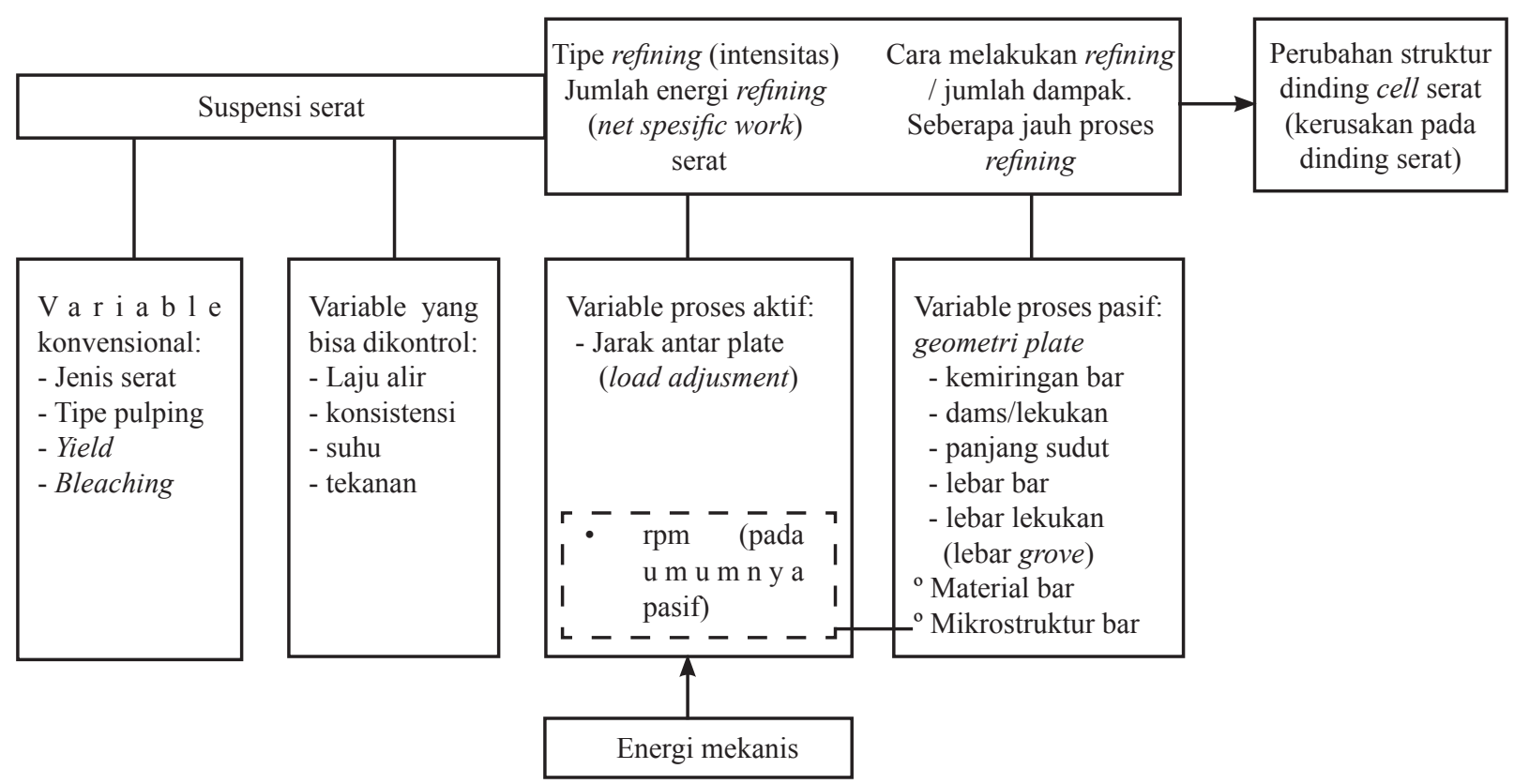

Gambar 1. Variable Proses Refining dan Dampak Proses Refining (Helle, T., 2003) 
Dalam proses refining intensitas dan jumlah energi terpakai memegang kendali utama dalam menghasilkan fiber bonding yang diinginkan. Intensitas terpakai dinyatakan dalan specific edge load $(\mathrm{SEL}, \mathrm{Ws} / \mathrm{m})$ atau specific surface load (SSL, Ws $/ \mathrm{m}^{2}$ ), sedangkan jumlah energi terpakai adalah jumlah energi netto yang dinyatakan dalam SRE (kWh/ton).

SEL adalah jumlah energi efektif yang dipakai persatuan total panjang bar rotor dan stator yang berpapasan dalam satu putaran mesin.

$$
S E L=\frac{P_{e}}{L_{s}}=\frac{\left(P_{t}-P_{o}\right)}{n_{r} \cdot n_{s} \cdot l_{r} \cdot l_{s} \cdot N}
$$

dengan $\mathrm{P}_{\mathrm{e}}$ adalah tenaga efektif yang ditransfer ke serat dalam satuan daya, dengan Pt adalah tenaga total yang digunakan untuk proses refining dan $\mathrm{P}_{\mathrm{o}}$ adalah idle power yaitu tenaga yang digunakan untuk memutar mesin refiner dalam kondisi kosong tanpa beban. sedangkan $\mathrm{n}, \mathrm{l}$ dan $\mathrm{N}$ adalah masing-masing jumlah bar pada rotor - stator, panjang bar rotor - stator, dan kecepatan putar refiner (Lumiainen, 2008).

SRE adalah jumlah energi efektif terpakai persatuan berat pulp yang direfining.

$$
S R E=\frac{P_{e}}{Q}
$$

dengan Pe adalah tenaga efektip yang ditransfer ke serat, dan Q adalah laju alir pulp dalam ton/ jam yang merupakan hasil perkalian antara laju alir volumetris $\left(\mathrm{m}^{3} / \mathrm{jam}\right)$ dan konsistensi pulp $\left(\right.$ ton $/ \mathrm{m}^{3}$ ) (Joris, 1991 and Lumiainen, 2008).

Nilai $\mathrm{P}_{\mathrm{o}}$ sendiri dapat diukur sebagai berikut (USDOE, 1992):

$$
P_{o}=V_{r m s} I_{r m s} \operatorname{Cos} \varphi=\frac{1}{2} V I \operatorname{Cos} \varphi=I^{2} R
$$

dengan $\mathrm{V}_{\mathrm{rms}}$ : voltage yang terbaca pada ACmeter (root mean square value), volt.

atau $\mathrm{V} r m s=\frac{\mathrm{V}}{\sqrt{2}}$

$\mathrm{I}_{r m s}$ : arus listrik yang terbaca pada AC-meter (root mean square value), Ampere. atau $\mathrm{I}_{\mathrm{rms}}=\frac{\mathrm{I}}{\sqrt{2}}$

$\operatorname{Cos} \varphi \quad$ : power factor jaringan listrik.

atau nilai $\mathrm{P}_{0}$ dan hubungan antara $\mathrm{P}_{0}$ dan $\mathrm{P}_{t}$ dapat didekati dengan persamaan:

$$
P_{o}=0.6 D^{4} N^{2.8}
$$

dengan $\mathrm{D}$ adalah diameter segmen refiner dan $\mathrm{N}$ adalah kecepatan putar refiner.

$$
P_{t}=P_{e}+1.2 P_{o}
$$

Nilai $\mathrm{P}_{\mathrm{o}}$ ini besarnya tergantung kondisi mekanis dari refiner yang diukur. dan masa pakai segment refiner (Joris, 1991).

Tujuan dari penelitian ini adalah pertama mencari kondisi operasi optimal dari mesin refiner untuk memperoleh pengembangan serat yang diinginkan yaitu yang memenuhi syarat minimal terhadap serat yang akan digunakan untuk membuat kertas kraft sehingga memenhi spesifikasi kertas kraft yang diinginkan. Kedua yaitu melaksanakan optimasi untuk memperoleh effisiensi energi tanpa mengorbankan kualitas serat yang diperoleh sehingga energi proses refining yang digunakan maupun jumlah mesin refiner yang digunakan dapat dikurangi, sehingga ada penghematan energi dan penghematan segment refiner.

\section{BAHAN DAN METODE}

Bahan bakupulpyang digunakanadalahBSWK (Bleached Soft Wood Kraft pulp) yang berupa pulp dari kayu spruce dengan panjang serat ratarata 2,22 mm, lebar serat 31-32 $\mu \mathrm{m}$ dan coarsness $0,211 \mathrm{mg} / \mathrm{m}$ serta mempunyai nilai derajat giling $15,4^{\circ} \mathrm{SR}$. Untuk mengetahui seberapa besar dampak proses refining di refiner konsistensi tinggi (HC Refiner) maupun refiner konsistensi rendah (LC Refiner) maka daya ikat serat yang dianalisa adalah murni daya ikat serat dari serat pulp hasil proses refining sebelum tercampur dengan beberapa aditif yang biasa dipakai pada proses pembuatan kertas. Hasil pengamatan 
diharapkan dapat digunakan sebagai panduan operasional mengingat dalam proses pembuatan kertas banyak sekali variable yang berpengaruh.

Perubahan struktur dinding serat yang diinginkan adalah perubahan struktur dinding serat yang berkontribusi positip terhadap daya ikat serat. Jenis pulp dan laju alir pulp sudah ditentukan terkait dengan kualitas dan kapasitas produksi yang diinginkan. Konsistensi pulp yang diumpankan ke HC Refiner dan LC Refiner adalah konsistensi yang optimal. Pola dari segmen refiner tidak diamati dan sudah baku sebagaimana telah digunakan. Umur segmen akan sangat menentukan pengembangan serat yang dihasilkan serta kapasitas perlakuan dari refiner tersebut, untuk itu pengamatan pengembangan serat harus selalu dilakukan setiap waktu sejalan dengan umur segment. Intensitas yang dinyatakan dalam SEL ataupun SSL yang merupakan fungsi dari efektif power dan pola segmen yang digunakan, dan SRE yang digunakan akan sangat menentukan pengembangan serat yang dihasilkan. Dalam hal ini nilai SRE divariasi untuk mendapatkan pengembangan serat yang diinginkan. Adapun variasi SRE yang digunakan adalah sebagai tertera pada Tabel 1.

Metode pengamatan yang dilakukan seperti pada Gambar 2 dengan mempertimbangkan waktu tinggal di masing-masing alat proses serta lama waktu yang diperlukan untuk mengubah kombinasi variable SRE yang akan digunakan sampai diperkirakan sudah mencapai kondisi tunak, sehingga sample yang diambil mewakili.

Dalam optimasi dual refining system, digunakan refiner konsistensi tinggi dan refiner konsistensi rendah. Optimasi dual refining system yang telah dilakukan ini masih perlu disempurnakan lagi dengan memilih kombinasi pemakaian energi yang ada, meskipun data yang diperoleh sudah dapat memberikan gambaran nyata bahwa spesifikasiserat pulpyang diharapkan telah dapat dicapai dengan kombinasi yang ada.

Tabel 1. Variable Pengamatan pada HC Refiner dan LC Refiner.

\begin{tabular}{cccc}
\hline \multirow{2}{*}{ Kode } & Waktu pengamatan & SRE HC Refiner, $\mathrm{kWh} / \mathrm{t}$ & SRE LC Refiner, $\mathrm{kWh} / \mathrm{t}$ \\
\cline { 2 - 4 } & (selang waktu, jam) & (selang tx +5 menit) & (selang tx +40 menit) \\
\hline 1A & to & 200 & 70 \\
1B & $\mathrm{t} 1=\mathrm{to}+1$ & 200 & 50 \\
1C & $\mathrm{t} 2=\mathrm{t} 1+1$ & 200 & 35 \\
1D & $\mathrm{t} 3=\mathrm{t} 2+1$ & 200 & 20 \\
2A & $\mathrm{t} 4=\mathrm{t} 3+1$ & 250 & 50 \\
2B & $\mathrm{t} 5=\mathrm{t} 4+1$ & 200 & 50 \\
2C & $\mathrm{t} 6=\mathrm{t} 5+1$ & 150 & 50 \\
2D & $\mathrm{t} 7=\mathrm{t} 6+1$ & 100 & 50 \\
Keterangan & to $:$ pengambilan sampel & Antara HC Refiner dan LC Refiner ada latency chest \\
& raw BSWK pulp & dengan waktu tinggal 30 - 40 menit \\
\hline
\end{tabular}

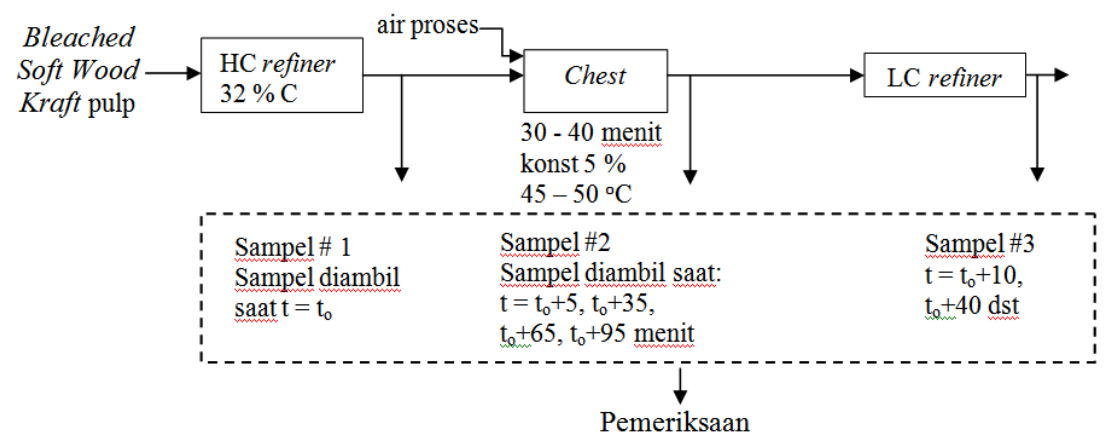

Gambar 2. Tempat Pengambilan Sampel dan Jadwal Pengambilan Sampel pada Proses Refining 
Pulp hasil slushing pertama di refining pada refiner konsistensi tinggi dan diamati dampak beberapa tingkat pemakaian energi refiner dari $100 \mathrm{kWh} / \mathrm{t}, 150 \mathrm{kWh} / \mathrm{t}, 200 \mathrm{kWh} / \mathrm{t}$, dan 250 $\mathrm{kWh} / \mathrm{t}$ terhadap pengembangan serat pulp hasil refining, setelah melewati latency chest direfining ulang pada refiner konsistensi rendah pada tingkat pemakaian energi refining yang berbeda dimulai dari $20 \mathrm{kWh} / \mathrm{t}, 35 \mathrm{kWh} / \mathrm{t}, 50 \mathrm{kWh} / \mathrm{t}$ dan $75 \mathrm{kWh} / \mathrm{t}$. Pengembangan serat yang terjadi diamati untuk menentukan pengembangan serat yang optimal pada tingkat pemakaian energi minimal. Blok diagram percobaan dan sampling pointnya seperti ditunjukkan pada Gambar 2. Dampak latency chest tidak dibahas disini.
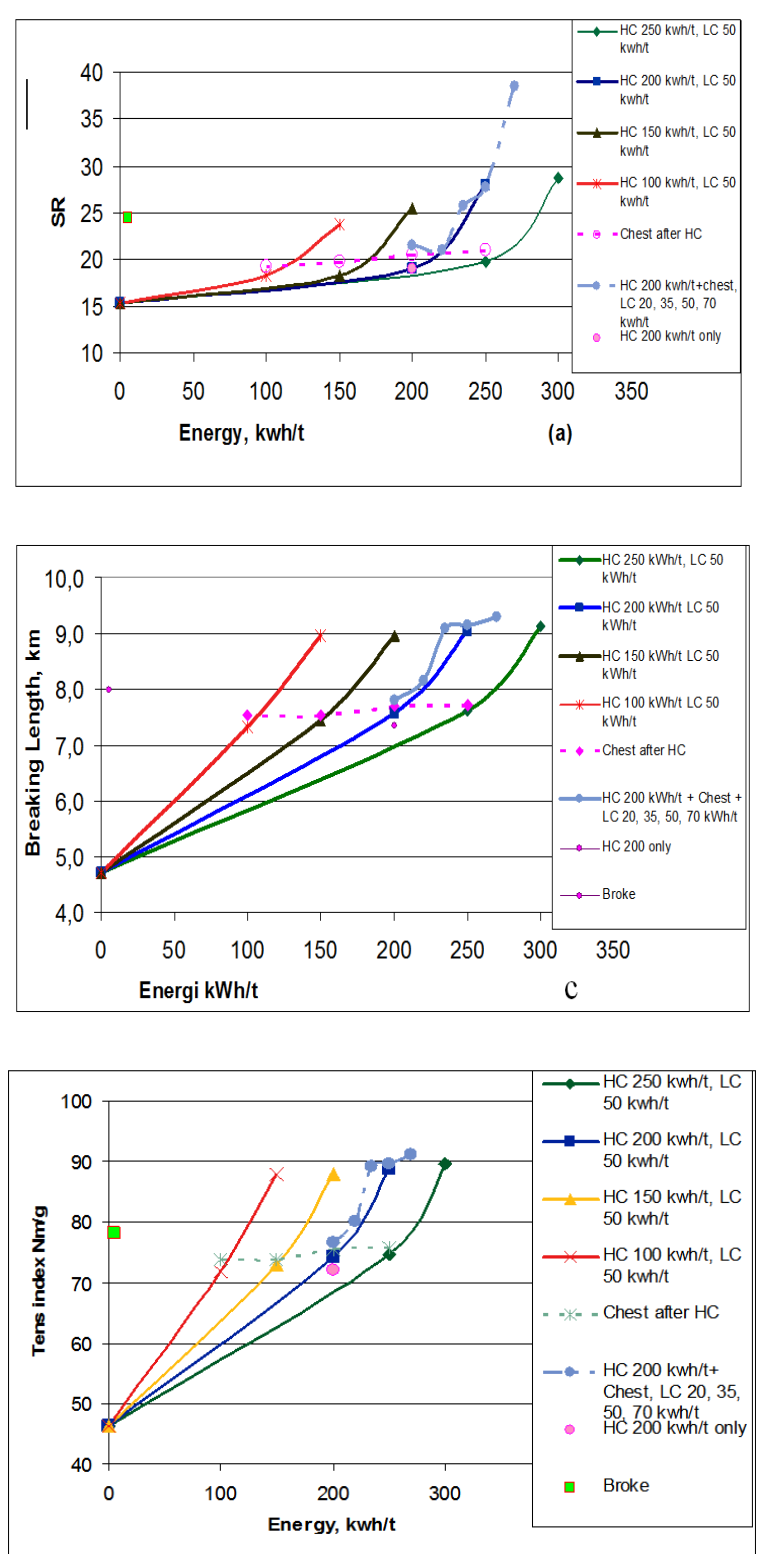

\section{HASIL DAN PEMBAHASAN}

\section{Optimasi Proses Refining (Kasus 1)}

Hasil percobaan diatas dianalisa dan dievaluasi dengan hasil sebagaimana tertera pada Gambar 3, terlihat bahwa kombinasi proses refining konsistensi tinggi $200 \mathrm{kWh} / \mathrm{t}$ dengan proses refining konsistensi rendah $35 \mathrm{kWh} / \mathrm{t}$ dapat menghasilkan pengembangan serat cukup baik, dengan hasil tear index, tensile index, dan TEA index yang paling optimal sementara nilai derajad gilingnya cukup baik sekitar $26^{\circ} \mathrm{SR}$ sehingga tidak mengganggu proses drainase pada proses pembentukan lembaran kertas basah di wire section.
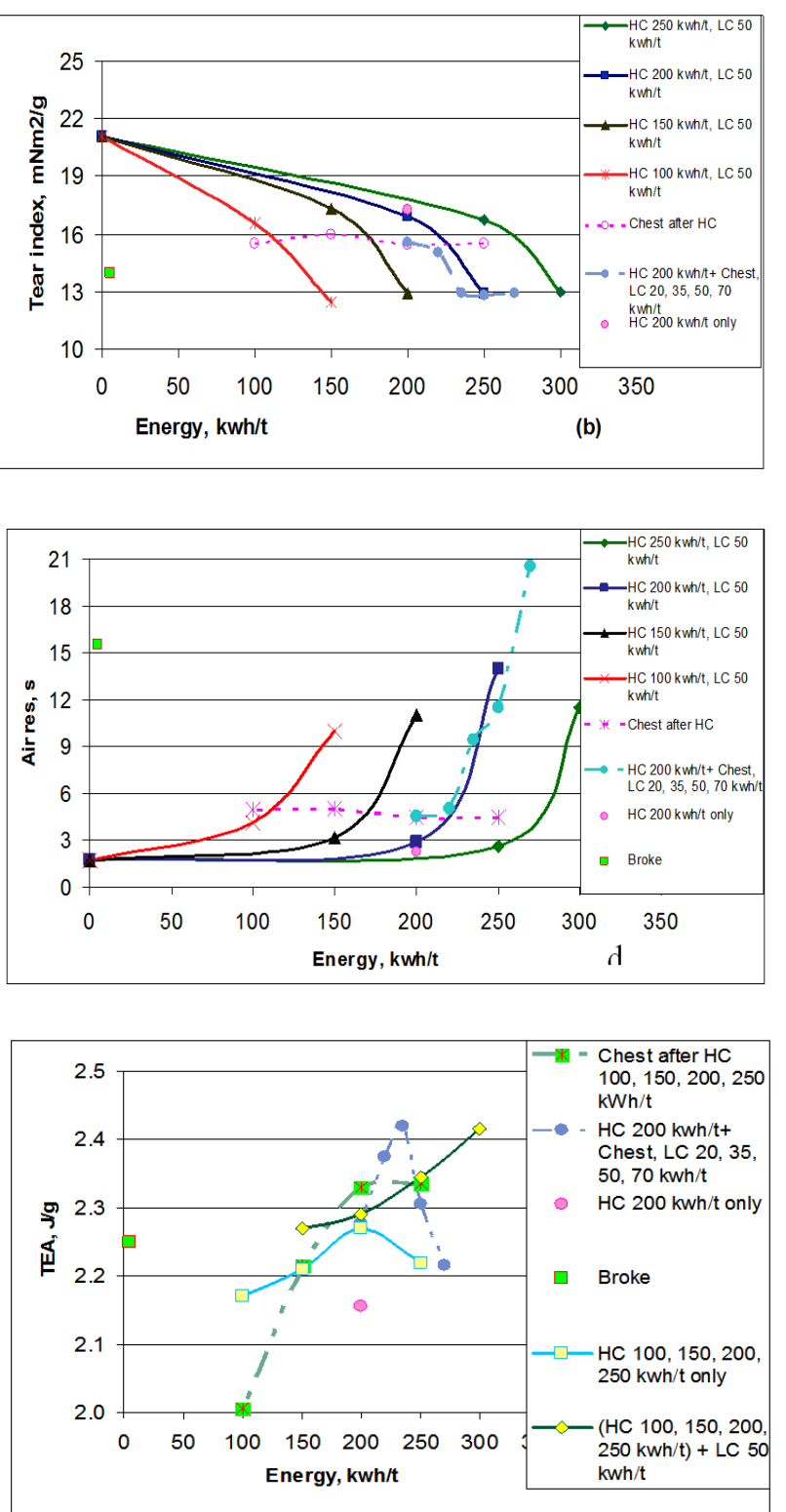

Gambar 3. Fiber Development pada Dual Refining System 


\section{Optimasi Energi Refiner (Kasus 2)}

Dalam kasus ini dilakukan optimasi pemakaian energi refining - SRE, $\mathrm{kWh} / \mathrm{jam}$ dalam upaya mendapatkan pengembangan serat yang paling optimal. Data yang dipakai disini adalah hasil perolehan optimasi energi refining pada kasus 1 dan evaluasi dilanjutkan terhadap pemakaian energi refining.

Kualitas produk yang diinginkan adalah membuat kertas white sack kraft dengan spesifikasi sebagai berikut: tensile index $>85$ $\mathrm{Nm} / \mathrm{g}$; tear index $>13 \mathrm{mNm}^{2} / \mathrm{g}$; breaking length $>8,5 \mathrm{~km}$; TEA Index $>2,3 \mathrm{~J} / \mathrm{g}$ (mutlak) dan air resistance $8-12$ detik (mutlak).
Spesifikasi white sack kraft diatas diperkirakan dapat dicapaijika pengembangan serat hasil proses dual refining dapat mencapai karakteristik seperti digambarkan pada Gambar 3 yang merupakan persyaratan minimal murni fiber bonding tanpa interfensi $\mathrm{MD} / \mathrm{CD}$ fiber orientation, filler, dan bahan kimia penolong. Dari Gambar 4 dan 5 dapat diamati bahwa pada proses refining dengan 2 buah HC Refiner masing-masing $200 \mathrm{kWh} / \mathrm{t}$ dan 4 buah LC Refiner masing-masing $35 \mathrm{kWh} / \mathrm{t}$ telah diperoleh pengembangan serat yang diinginkan tetapi ada penambahan pemakaian energi sebesar 2,4\% terhadap kombinasi 2 buah HC Refiner masing-masing $150 \mathrm{kWh} / \mathrm{t}$ dan 4 buah LC Refiner masing-masing $50 \mathrm{kWh} / \mathrm{t}$, dan apabila optimasi

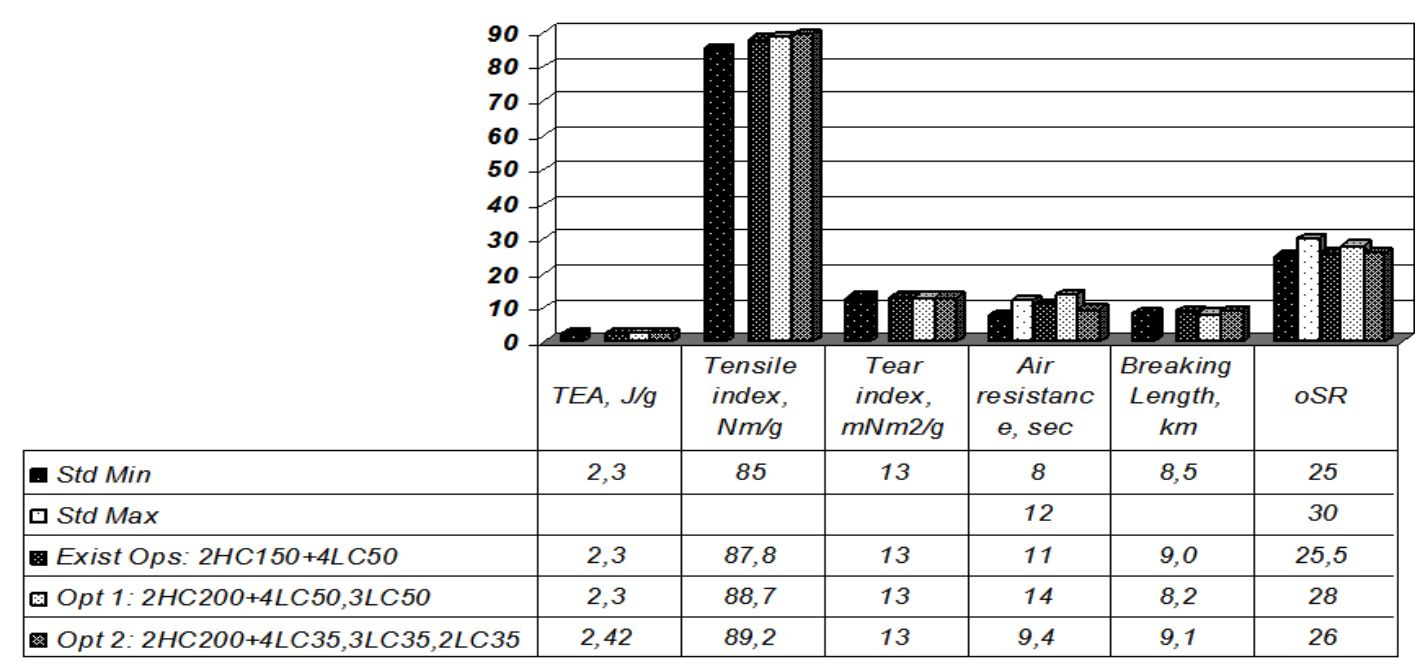

Ganbar 4. Optimasi Energi dan Optimasi Pemakaian DDR.

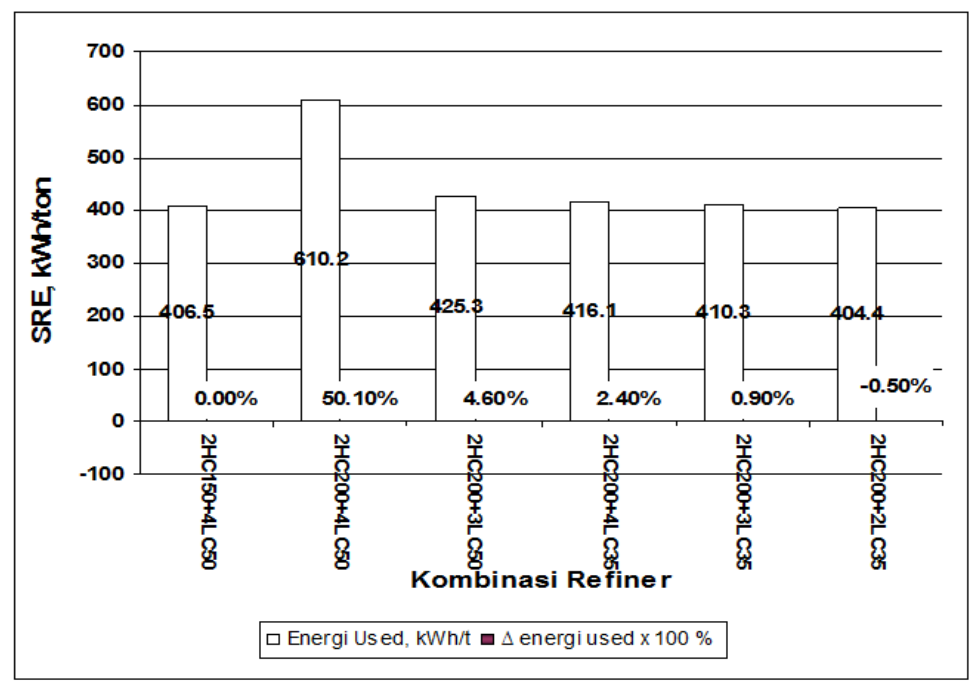

Gambar 5. Pemakaian Energi dan Penghematan Energi (kWh/ton) pada berbagai Kombinasi Pemakaian Refiner 
dilanjutkan dengan mengoptimalkan DDR yang ada diperoleh bahwa kombinasi 2 buah $\mathrm{HC}$ Refiner masing-masing $200 \mathrm{kWh} / \mathrm{t}$ dan 2 buah LC Refiner masing-masing $35 \mathrm{kWh} / \mathrm{t}$ telah cukup ideal untuk proses refining dimaksud dengan penghematan energi sebesar $0,5 \%$.

Sementara itu kombinasi 2 HC Refiner masing-masing $200 \mathrm{kWh} / \mathrm{t}$ dan $4 \mathrm{LC}$ Refiner masing-masing $50 \mathrm{kWh} / \mathrm{t}$ maupun kombinasi 2 HC Refiner $200 \mathrm{kWh} / \mathrm{t}$ dan 3 LC Refiner masingmasing $50 \mathrm{kWh} / \mathrm{t}$ menghasilkan pemborosan energi sementara itu spesifikasi serat pulp yang diinginkan tidak tercapai.

\section{KESIMPULAN}

1. Pengembangan serat yang diinginkan dapat diperoleh dengan kombinasi 2 HC Refiner masing-masing $150 \mathrm{kWh} / \mathrm{t}$ dan $4 \mathrm{LC}$ Refiner masing-masing $50 \mathrm{kWh} / \mathrm{t}$ dengan total pemakaian energi 406,5 kW/t.

2. Pengembangan serat serupa juga dapat diperoleh dengan kombinasi 2 HC Refiner masing-masing $200 \mathrm{kWh} / \mathrm{t}$ dan 4 LC Refiner masing-masing $35 \mathrm{kWh} / \mathrm{t}$ dengan total pemakaian energi 416,1 kW/t sehingga terdapatpemakaian energilebih sebesar 2,4\%.

3. Pengembangan serat serupa juga dapat diperoleh dengan kombinasi 2 HC Refiner masing-masing $200 \mathrm{kWh} / \mathrm{t}$ dan $3 \mathrm{LC}$ Refiner masing-masing $35 \mathrm{kWh} / \mathrm{t}$ dengan total pemakaian energi 410,3 kW/t sehingga terdapat pemakaian energi lebih besar $0,9 \%$ akan tetapi ada penghematan pemakaian mesin LC Refiner 1 buah.

4. Pengembangan serat serupajuga dapat diperoleh dengan kombinasi $2 \mathrm{HC}$ Refiner masing-masing $200 \mathrm{kWh} / \mathrm{t}$ dan 2 LC Refiner masing-masing 35 $\mathrm{kWh} / \mathrm{t}$ dengan total pemakaian energi 404,4 $\mathrm{kW} / \mathrm{t}$ sehingga terdapat penghematan energi sebesar $0,5 \%$ dan penghematan pemakaian mesin LC Refiner 2 buah.
5. Kombinasi 2 HC Refiner masing-masing 200 $\mathrm{kWh} / \mathrm{t}$ dengan $4 \mathrm{LC}$ Refiner masing-masing 50 $\mathrm{kWh} / \mathrm{t}$ ataupun dengan $3 \mathrm{LC}$ Refiner masingmasing $50 \mathrm{kWh} / \mathrm{t}$ tidak dapat dilakukan karena karakteristik serat atau pengembangan serat yang diinginkan tidak tercapai sementara pemakaian energi sangat berlebih.

\section{DAFTAR PUSTAKA}

Erikson, O., et al., 2008, Theoretical Outline of the Cause for Observed Cavitations in a Low Consistency Refiner, Nordic Pulp and Paper Research Journal, Vol. 23, No.2.

Helle, T., 2003, The Fundamental of Pulp Beating, Lecture Handout, NTNU, Norway and AIT Bangkok.

Joris, G., 1991, Pulp Refining Process, Vol.1, Acieries de Bonpertuis, Seyssinet.

Joris, G., 2007, Industrial Refining Process vs Theory, TAPPSA Journal.

Lumiainen, J, 2008, Refining of Chemical Pulp, in Paulapuro, H., Papermaking Part 1, Stock Preparation and Wet End, 2nd.ed Papermaking Science and Technology Series, Jyvaskyla, Finland. pp $87-122$.

Lundin, T. et al., 2008, Fiber Trapping in Low Consistency Refiner - New Parameter to Describe The Refining Process, Tappi Journal, July 2008.

Smook, G. A., 2002, Handbook for Pulp and Paper Technologist, 3 th. ed., Tappi, Atlanta. GA.

Wikanaji, D., 2003, Micro Compression and Curl Removal of Fiber in Stock Prep and The Effect of Refining Energy on the Chemical Pulp Properties, Project Report No. D -1303, UPM Kymmene, Pietarsari Finland.

Qian X. and Tessier, P., 1995, A Mechanistic Model for Predicting Pulp Properties from Refining Operating Condition., Tappi Journal, Vol. 78, No. 4, 215-222.

U.S Department of Energy (USDOE), 1992, DOE Fundamentals Handbook, Electrical Science, vol.4,U.SDepartmentofEnergy,USA.pp 5-30. 